\title{
Teachers'Well-Being Through Work Engagement among Montfortian Schools in Asia
}

\author{
Arul Rayan Irudayaraj \\ Montfort Brothers of St.Gabriel \\ arulrayani2018@gmail.com
}

\section{Abstract}

The current study focuses on the well-being of Montfortian teachers in terms of work engagement in five Asian countries such as India, Singapore, Malaysia, Thailand, and the Philippines. Data were collected using a survey questionnaire from 427 teachers. Differences in the level of work engagement were tested using Analysis of Variance. Regression models examined the significant predictors and organizational outcomes of work engagement. Perceived Organizational Support and Servant Leadership significantly predicted Work Engagement in Singapore and Thailand. Work Engagement had a positive impact on Organizational Citizenship Behavior (OCB) directed toward organizations in Singapore, Malaysia, Thailand, and the Philippines. It had a significant effect on OCB directed toward teachers in Malaysia and Thailand. Work Engagement also predicted Affective commitment in India and Singapore. This study produces cross-national knowledge about work engagement. Further, it provides a better understanding of teachers' well-being in terms of work engagement and its effect on organizational variables in the school context.

Keywords: work engagement, servant leadership, Organizational Citizenship Behavior, organizational commitment, perceived organizational support, and teachers' well-being

\subsection{Introduction}

The economic, social as well as emotional growth of a nation depends on the soundness of the educational background of its workforce. Teachers, in particular, play a very influential role in shaping a student's character and outlook towards life and his/ her various experiences. It is extremely important then that teachers love their jobs (lyer, 2016). In today's workplace, attracting and retaining good employees are a top priority in both large and small organizations (llagan \& Javier, 2014).

According to Bakker, Schaufeli, Leiter, and Taris
(2008), work engagement means a positive, fulfilling state of work-related well-being. It is an important index for the quality of work life. It can be seen as a crucial factor in increasing the performance of the employee and, thereby, the organization's level of efficiency. Today, the well-being of the employees has become critical to the development and growth of the industry.

Deligero and Laguador (2014) stated that higher level of work engagement makes employees become more productive, vigorous, dedicated, and enthusiastic to perform their duties and 
responsibilities. In the realm of education, highly engaged teachers can be considered as great assets to the institutions. Their work ethics and professional relationships are closely intertwined on a daily basis.

The Montfortian Schools are operating in five countries in Asia such as India, Singapore, Malaysia, Thailand, and the Philippines. In India, the Montfortian Institutions provide academic, industrial trainings, and special education. In some Montfortian schools, special education is integrated in the mainstream schools. Vocational schools are subsidized by the Directorate of Technical Education and committed to the transformation of the youth particularly the poor and the marginalized.

In Singapore, The Assumption Pathway is an industrial school accredited by the Institute of Technical Education (ITE). It offers vocational and character development programs developed in collaboration with various agencies. It is committed to the vocational training of students who are unable to access or complete secondary education. It helps them to achieve personal success. The other academic schools instill in their students the Montfortian values of service and compassion.

In Malaysia, three Montfortian schools are dedicated to the service of youth particularly, the orphans, the poor, and the marginalized through technical and vocational training. They also provide boarding facilities to their students and help them to discover their full potentials and enable them to become responsible, effective, and worthy citizens of the community. They train the students for both institutional and Sijil Kemahiran Malaysia (Malaysian Skill Certificates).

In, Thailand, the Montfortian education mission was established in 1901. It interweaves education with Thai culture and traditions.

In the Philippines, the two Monfortian schools are run by Indian nationals (they are Indian religious brothers of St. Gabriel) under the Montfortian Education charter. They offer both vocational and academic trainings to the poor and the marginalized youths from distant islands.

All these Montfortian Educational institutions play a critical role in nation building through their academic, technical-vocational, and special education programs established since 1900.

Like many of the private educational institutions in Asia, the Montfortian institutions are also confronted with the negative consequences of teachers suffering from burnout. Teachers who experience ill-health call in sick and are are, thus, less productive.. This will certainly affect the performance of students. As stated by Pakarinen et al., (2010) teacher stress stems from classroom management and student discipline. This affects the commitment of teachers and the efficiency of the schools. Since these educational institutions are operating in crosscultural contexts, there may be many factors that could influence the work engagement of teachers. There is a limited research for understanding the antecedents and consequences of work engagement among Monfortian teachers in the aforementioned countries in Asia.

The Job Demand - Resource (JD-R) model explains that every occupation may have its own specific risk factors associated with job stress. These factors can be classified particularly into two general categories - job demands and job resources (Bakker and Demerouti, 2007). This study specifically focuses on the motivational process of the JD-R model. According to the motivational process of the JD-R model, job resources model like the Organizational Support and Servant Leadership can influence work engagement. Further, work engagement might influence Organizational Commitment and 
Organizational Citizenship model.

Further still, much of the research in the area of work engagement has been based on a business model that may not be applicable to education. This study aims to examine the comprehensive model of predictors and outcomes of work engagement among teachers in the Montfortian Schools in India, Singapore, Malaysia, Thailand, and the Philippines. Consequently, it will help develop a better understanding of a model of teachers' work engagement in Montfortian schools in the said five Asian countries.

\section{Research Questions}

This research investigates the work engagement among Montfortian teachers. Specifically, it aims to answer the following questions:

1. What is the level of work engagement among Montfortian teachers in India, Singapore, Malaysia, Thailand, and the Philippines?

2. Are there significant differences in the level of work engagement among Montfortian teachers in India, Singapore, Malaysia, Thailand, and the Philippines?

3. What are the significant predictors of work engagement among Montfortian teachers in India, Singapore, Malaysia, Thailand, and the Philippines?

4. What are the significant outcomes of work engagement among Montfortian teachers in India, Singapore, Malaysia, Thailand, and the Philippines?

\section{Hypotheses}

$\mathrm{H} 1$ : There are significant differences in the level of work engagement among Montfortian teachers in India, Singapore, Malaysia, Thailand, and the Philippines.
$\mathrm{H} 2$ : Servant leadership significantly predicts work engagement among Montfortian teachers in India, Singapore, Malaysia, Thailand, and the Philippines.

H3: Perceived organizational support significantly predicts work engagement among Montfortian teachers in India, Singapore, Malaysia, Thailand, and the Philippines.

$\mathrm{H} 4$ : Work engagement significantly predicts organizational commitment among Montfortian teachers in India, Singapore, Malaysia, Thailand, and the Philippines

$\mathrm{H} 5$ : Work engagement significantly predicts Organizational Citizenship Behavior (OCB-I) and (OCB-O) of Montfortian teachers in India, Singapore, Malaysia, Thailand, and the Philippines

\section{Theoretical and Conceptual Framework}

This study is anchored on Organizational Support Theory (Eisenberger, Huntington, Hutchinson, \& Sowa, 1986) and the Job Demand-Resource Model ((Demerouti, Bakker, Nachreiner, \& Schaufeli, 2001). The Organizational support theory holds that employees form a general perception if and when the company values their contributions and cares about their well-being. Such perceived organizational support (POS) would increase the work engagement of employees and their felt obligation to help the company reach its objectives.

According to the JD-R model, every occupation may have its own specific risk factors associated with job stress. These factors can be classified particularly into two general categories - job demands and job 
resources (Bakker \& Demerouti, 2007). This study focuses on the motivational process of the JD-R model.

Job resources also refer to physical, psychological, social, and organizational aspects of the job. Such aspects denote the following:

1. reduce job demands and the associated physiological and psychological costs;

2. are functional in achieving work goals; and

3. stimulate personal growth, learning, and development (Schaufeli \& Bakker, 2004).
Work engagement is defined as a "positive, fulfilling, work-related state of mind that is characterized by vigor, dedication, and absorption" (Schaufeli, Salanova, Gonzales-Roma, \& Bakker, 2002). The JD-R model proposes that job resources are assumed to have motivational potential, which leads to high performance through low cynicism and high engagement (Bakker \& Demerouti, 2007). This study focuses on Organizational and Interpersonal relationships of the job resources: Perceived organizational support and Servant Leadership.

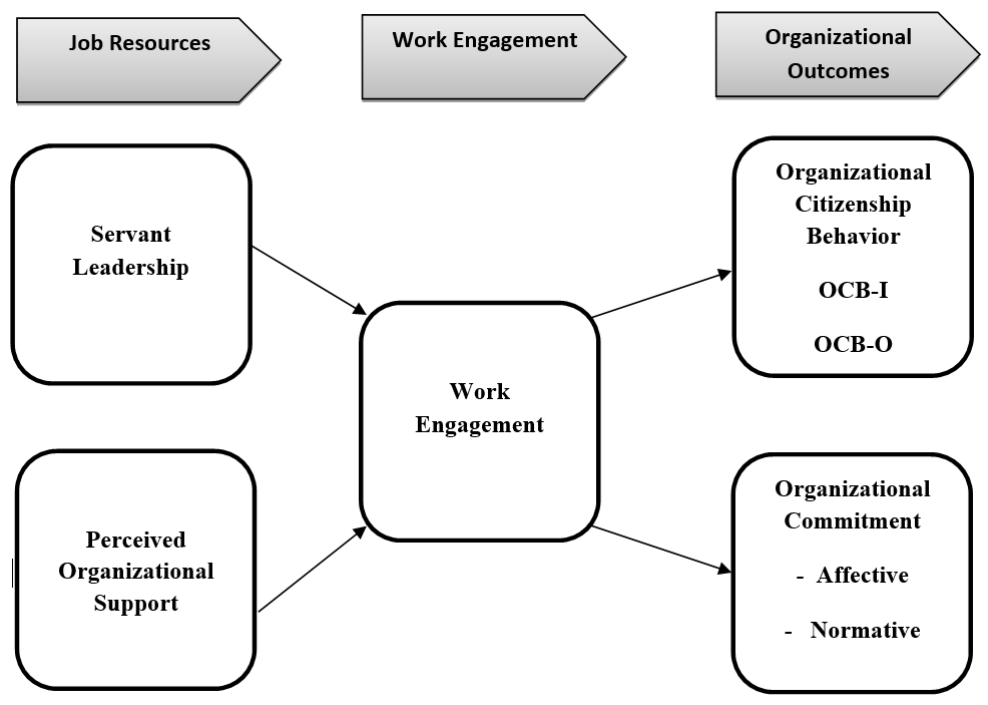

Figure 1. Motivational Process of JD-R Model and Work Engagement

\section{Related Literature}

\section{The Charism of Montfortian education and teachers'} well-being

The Montfortian education has the goal of transforming individuals and societies to be spiritually inspired, be communitarian, fraternal, and just. The Montfortian Education Charter framed in 2010 has the following charisms and core values: Spiritual Vision, Inclusive Education. Incarnational
Methodology, Innovation and Creativity, The Best Interest of the Child, Partnership and Networking, Respect for Community of Life; and Quest for Excellence (MEC, 2010). These core dimensions of charism play a significant role in the educational process of the Montfortian schools in Asia run by the Montfort Brothers of St. Gabriel (Rayan, 2013).

The incarnational methodology, in particular, promotes genuine empathy, sharing in the situation 
of members in the education community as a participatory process (Montfortian Education Charter, 2010). Teachers are considered as great partners in the Montfortian education. They play a crucial role in the transformation of youth and society. Therefore, the care for teachers and their well-being should be paramount in the Montfortian education charter. A study conducted among the Montfortian Technical Vocational Education and Training (TVET) Schools in Asia indicated that the said schools showed genuine empathy, care and concern for students most of the time (Rayan, 2013). In the midst of tough competition and academic success of schools, the process of promoting wellbeing among teachers remains a huge challenge for Montfortian schools in Asia.

\section{Work Engagement and its importance}

It is pointed out that work engagement is one of the most important contributing factors to the performance and the success of the organizations (Kataria, Garg, \& Rastogi, 2013). Evidence has been sustained in respect to its effect to the persons and the organizations (Pati, 2012; Pati \& Kumar,2010). Work engagement is defined as an effective and positive cognitive state, vigor, commitment, and absorption. (Roozeboom \& Schelvis, 2015). It is a condition in which an employee has high vigor, dedication, and absorption in carrying out her or his duties and responsibilities. Vigor can be defined as strength of body and mental resilience. This is when an employee is willing to work harder despite the difficulties. Dedication means that an employee is engaged in his or her work and meets its challenges head-on. Absorption can be the state when an employee is preoccupied with his or her work and sticking to it till it is done (Schaufeli \& Bakker, 2004).

Further, Pasion-Caiani (2015) explained that work engagement is the employee's intent to stay, willingness to refer the organization to others, and discretionary effort made on behalf of the employee in their work. Schaufeli (2012) points out that the concept of work engagement, which first emerged in the 1990's, is new both for the academe and the corporate world. It also means that an employee is actively involved with company activities and routines on a daily basis. He or she has passion, absorption, commitment, focus, and energy while at work. Work engagement then is considered to have great significance for both employees and organizations (Steger, Littman-Ovadia, Miller, Menger, \& Rothman, 2013).

Employee Engagement is a workplace approach designed to ensure that employees are committed to their organization's values and goals. They are highly motivated to contribute to the development and growth of the company (Vorina, Simonic, \& Vlasova, 2017; Agrawal, 2015).

\section{Work Engagement and Teachers' well-being}

As defined by Roozeboom and Schelvis (2015), work engagement correlates with a positive cognitive state, vigor, commitment, and absorption. It could be said then that engaged teachers are energetic; they possess mental toughness to perform their job even if there are difficulties and challenges. They take pride and show enthusiasm in doing their work. They feel positive and are preoccupied with their work which are in contrast with those employees who suffer from burnout. Burnout leads to ill-health but work engagement promotes wellbeing among teachers. As Ryan and Deci (2011) put it, well-being is "open, engaged, and healthy functioning" (p.47). Thus, teachers who are motivated to work carry out their functions with vigor, dedication, and absorption. A study involving 
newly qualified teachers says that work engagement and teacher efficacy correlate with job satisfaction. Teachers who are burnout have the tendency to to quit (Høigaard Giske, \& Sundsli, 2011). Shimazu, Schaufeli, Kubota and Kawakami (2012) indicate that well-being and work engagement are positively associated. Work engagement also promotes wellbeing and performance.

\section{Work engagement among teachers in Asia}

A survey conducted among 141 secondary teachers in Hyderabad and Andhra Pradesh in India shows that teachers' work engagement is generally high (overall $M=5.40$ on the 7-point scale; $M=5.14$, $5.65,5.41)$ under vigor, dedication, and absorption subscales) (Delaram and Chehelmard, 2013). In the Philippine context, a study among employees in a higher education institution showed that the school employees have high work engagement in terms of vigor, dedication, and absorption with a highly satisfying performance evaluation rating. Married employees are more dedicated to working due to their matured role and responsibilities over their families. Employees belong to the age bracket with more than 40 years have higher engagement towards work due to the level of their expertise in carrying out various tasks every day compared to those young and middle-aged employees (Deligero \& Laguador, 2014).

Another empirical study among 417 elementary teachers in BangkokMetropolis administration posits a model that personal resources, job resources, and job demand influence work engagement, which in turn predict work behavior (i.e., teacher role behavior and organizational citizenship behavior). Further, this study confirmed that personal resources (i.e., psychological immunity and intrinsic motivation) and job resources (i.e., justice climate, teacher- student relationships, support from coworkers, and supports from supervisors) positively affected work engagement. Work engagement had an impact on teachers' role behavior and organizational citizenship behavior (Choochom, 2016).

\section{Predictors of work engagement behavior among teachers}

Predictors of work engagement may vary between individuals, organizations, occupations, sectors, and regions. It has been suggested that there is not one single predictor of work engagement, but rather numerous predictors that can contribute to employees' experiences of engagement (Shuck, Rocco, \& Albornoz, 2011). Since much of the research in the area of work engagement has been based on a business model that may not generalize to education, this study aims to examine the predictors of work engagement among teachers. Work engagement among teachers has been receiving special attention in the field of Education (Bakker \& Demerouti, 2007).

A study conducted among Filipino teachers at an Asian University confirmed that providing the employees with enough services would generate an impact on their behavior to become more engaged in their work assignments (Bay, An, \& Laguador, 2014).

It is clear that employee engagement is critical to organizational success. A study which tested the relationship of job satisfaction and employee engagement among the staff of private higher education institutions (PHEls) in Thailand recommended that the administrators should establish both intrinsic factors and extrinsic factors of job satisfaction to increase job satisfaction among staff, as well as build an engaging work environment consisting of aligning effort with strategy, 
empowerment, teamwork and collaboration, growth and development, and support and recognition for having an engaged work-life (Tepayakul \& Rinthaisong, 2018).

\section{Servant Leadership (SL) and Work Engagement}

Servant leadership has been defined by Greenleaf (1977) as a leadership style that focuses on to their fullest of task effectiveness, community stewardship, self-motivation, and future leadership capabilities (Liden, Wayne, Zhao, \& Henderson, 2008). It has been suggested that a servant leader is able to inspire their followers: serving them, and then by guiding them (Greenleaf, 1977).

While reflecting on the characteristics of servant leadership, Liden, Panaccio, Meuser, $\mathrm{Hu}$, and Wayne (2014) noted that because servant leaders are humble and focused on followers rather than themselves, this allows this particular leadership style to stimulate positive relationships with followers. In addition, servant leadership promotes employees' spiritual development, wellbeing, and work outcomes, such that they start to become more engaged, open-minded, patient and considerate in the workplace. This promotes a strong conduit for enhancing work engagement (Chen, C.-Y, Chen C.$H$, \& Li, 2013).

Further, Bakker and Leiter (2010) asserted that in the contemporary world of work, to compete effectively, companies not only must recruit the top talent but must also inspire and enable employees to apply their full capabilities to their work. This suggests that school organizations need teachers, who are psychologically connected to their work; who are willing and able to invest themselves fully in their roles; that are proactive and committed to their organizations' goals and promote efficiency.

In other words, there can be an increase in work engagement among teachers if there is a sound sense of trust in the competence and capability of their leaders. Furthermore, supervisory coaching in the form of assisting employees in locating their goals, organizing their work, highlighting drawbacks, taking a keen interest in their professional and career advancement, and offering advice as needed, has been positively related to work engagement (Schaufeli \& Salanova, 2007). Drawing from research on the relationship between work engagement and servant leadership, the relationship among employees of four information technology (IT) companies showed that servant leadership enhances work engagement (DeClercq, Bouckenooghe, \& Matsyborska, 2014). Another study among government employees disclosed that servant leadership has a positive and significant relationship to work engagement and job satisfaction (Rayan, Wong, \& Banas, 2015).

\section{Perceived organizational support (POS) and Work Engagement}

The perception of organizational support is the extent of belief of workers that their organization appreciates their contributions and that it cares about their well-being (Krishhan \& Mary, 2012). Perceived organizational support has an important role both for the institution and for workers. Perceived organizational support enables workers to feel safe and feel that the power of the organization they work for behind them (Özdevecioğlu, 2003), makes workers feel that their organization supports them and stays right beside them all the time. This enables their workers to become more attached to their jobs in a safe working environment and gives them the idea not to leave their working places (Akkoç, Caliskan, \& Turunc, 2012)

Perceived organizational support (POS) has 
continued to surface and has attracted strong interest among researchers and practitioners. Perceived organizational support has been found to predict many variables such as work engagement (Saks \& Rotman, 2006).

Similarly, Nurul, Jo, Siew, and Murali (2015) in their study among teachers in Malaysia based on the Job Demands-Resources Model confirmed that there is a positive relationship between job resources provided by the school and work engagement of the teachers. The literature discussed in this section confirms that when employees feel supported by their organization, they are likely to reciprocate by investing time and energy into meeting the goals of the organization (Bakker, Albrecht, \& Leiter, 2011).

\section{Work Engagement and Organizational commitment}

Work engagement and organizational commitment are among the most studied topics in a range of fields, including human resource development (HRD) and organization development (OD). The value of such work is evident in the direct influence of work engagement and organizational commitment on employee well-being and organizational performance. However, scholars have divergent perspectives on the relationship between these two concepts. While some studies have examined work engagement as a precursor to organizational commitment, others have investigated work engagement as an outcome of organizational commitment (Kim et al, 2017).

According to a study among junior executives working in the private sector of Bangladesh highlighted that employee engagement has a positive effect on affective commitment as well as normative commitment. However, it is found that employee engagement has no significant effect on continuance commitment (Akhund \& Shamsul, 2017).

\section{Work Engagement and Organizational citizenship behavior}

Organ, Podsakoff, and Mackenzie (2006) pointed out that the concept of organizational citizenship behavior (OCB) is considered as discretionary not directly or explicitly recognized by the formal reward system and in aggregate promotes the efficient and effective function of the organization.

When employees are motivated with organizational resources, they tend to be engaged at work and exhibit positive interpersonal relationships and those with the company (Rayan, Dr, \& Wong, 2017).

\subsection{Methodology}

\section{Research Design}

This study employed a descriptive-correlational method to measure and tests the predictors and outcomes of work engagement in an educational setting in five countries in Asia.

\section{Sample}

The respondents of the study consisted of 427 teachers from 13 Montfortian schools in five (5) Asian countries. The sample was composed of males (40.7\%) and females (59.3\%). The respondents of the study were composed of $11.21 \%$ from the Philippines, $46.96 \%$ from Singapore, $7.48 \%$ from Malaysia, $12.85 \%$ from Thailand and $21.5 \%$ from India.

\section{Research Instruments}

The questionnaire had six sections. The first section solicited the personal profiles of the respondents; the second section measured the servant leadership behaviors of school leaders using the Winston \& Fields (2015). Essential Servant Leadership Behavior Instrument, with 10 items. It is 
a single-dimensional tool with a Five-point Likert scale. The reliability test on this scale resulted in a Cronbach coefficient alpha of 0.96 . The third section measured perceived organizational support using an 8 items scale developed by Eisenberger et al., (1986). The fourth section utilized a 17-item Utrecht Work Engagement scale Schaufeli et al., (2002) to measure the level of work engagement of teachers. Although there are other measurement tools for work engagement readily available, the most prominent one in educational research is the Utrecht Work Engagement Scale (Klassen, et al., 2012). The fifth section employed a shortened version of Paul and Foxzy's Organizational Citizenship Behavior Checklist (20 item scale) recommended by Fox, Spector, Goh, Bruursema, and Kessler (2012). This scale measured the level of teachers' citizenship behaviors directed toward their school organization (OCB-O) as well as co-teachers OCB-P) using a Five-point Likert Scale. The sixth section measured teachers' level of organizational commitment using the modified organizational commitment scale developed by Meyer, Allen, and Smith (1993). It measured only the Affective ( 6 items) and Normative commitment ( 6 items) of teachers. All the scales used a five-point Likert scale. The research instruments met the requirements for reliability and validity. The internal consistency of the items in the instruments was confirmed by the following reliability coefficients (Alpha) for perceived organizational support, affective commitment, and normative commitment were $a=0.88,0.87$, and 0.84 respectively.

\section{Data Analysis}

The descriptive statistics determined the level of work engagement behaviors exhibited by the Montfortian teachers across the countries in Asia. One-way analysis of variance (ANOVA) was used to test the significant differences in the level of work engagement behaviors among the five (5) countries in Asia. The regression analysis was employed to test the predicting effect of Job resources such as servant leadership and perceived organizational support. It also tested the outcomes of work engagement such as Employee Commitment (Affective and Normative), and Organizational Citizenship Behavior directed to Individuals and organizations. All the data analyses were performed with the aid of Statistical Package for Social Science (SPSS) version 21.0 Software

\subsection{Results}

Table 1 presents the level of Work Engagement of Montfortian teachers across countries in Asia. The Montfortian teachers in the Philippines, India, and Thailand exhibited a very high level of Work engagement, while the Montfortian teachers in Malaysia and Singapore exhibited a high level of Work Engagement behaviors.

Table 1. Level of work engagement among Montfortian teachers across countries in Asia

\begin{tabular}{lcccc}
\hline Country & N & SD & Mean & Interpretation \\
\hline Philippines & 48 & .3514 & 4.59 & Very High \\
India & 92 & .5349 & 4.35 & Very High \\
Thailand & 54 & .6838 & 4.22 & Very High \\
Malaysia & 32 & .6971 & 4.11 & High \\
Singapore & 201 & .6579 & 4.05 & High \\
\hline
\end{tabular}


Further, a one-way ANOVA was conducted to compare the work engagement behaviors of teachers in India, Singapore, Malaysia, Thailand, and the Philippines. There was a significant difference in the work engagement behaviors among teachers in the Asian countries at the $p<.05$ level $[F(2,422)=$ 9.519, $\mathrm{p}=0.00]$.

In addition, Post hoc comparisons using the Sheffe test indicated that the mean score in Philippines ( $M=4.59, S D=.3514$ ) was significantly different from Singapore $(M=4.05, S D=0.6579)$, Malaysia ( $M=4.11, \mathrm{SD}=.6971)$, and Thailand $(\mathrm{M}=$ 4.22, $S D=0.6838)$. However, work engagement behavior in the Philippines did not significantly differ from India ( $M=4.35, S D=0.5349$ ).

Table 2 reveals that Servant leadership significantly predicted the work engagement behaviors of teachers with a moderate correlation in Singapore $\left(\beta=0.243, R_{2}=.059, p<.05\right)$ and a weak correlation in Thailand $\left(\beta=.442, R_{2}=.195, p<.05\right)$. Therefore, servant leadership is one of the significant predictors of work engagement among Montfortian teachers in Singapore and Thailand. It was also noted that the Servant leadership accounts for 5.9\% variance on the work engagement of teachers in Singapore and $19.5 \%$ among teachers in Thailand. The findings also disclosed that servant leadership was not a significant predictor in India, Malaysia, and the Philippines. In addition, Perceived organizational support also was a significant predictor of the work engagement behavior of teachers with moderate correlation in Singapore $\left(\beta=.440, R_{2}=.193, P<-05\right)$ and Thailand $\left(\beta=.339, R_{2}=, p<.05\right)$.

Table 2. Predictors of Work Engagement among Montfortian teachers in India, Singapore, Malaysia, Thailand, and the Philippines

\begin{tabular}{lcccccccc}
\hline \multirow{2}{*}{ Country } & Hypotheses & Variables & $\mathbf{n}$ & Mean & SD & \multicolumn{2}{c}{$\begin{array}{c}\text { Work } \\
\text { Engagement }\end{array}$} & Result \\
\cline { 7 - 8 } & & & & & & $\mathbf{R}^{\mathbf{2}}$ & $\mathbf{B}$ & \\
\hline India & $\mathrm{H}_{2}$ & $\mathrm{SL}$ & 92 & 4.31 & 1.078 & 0.022 & 0.149 & Not a Predictor \\
& $\mathrm{H}_{3}$ & $\mathrm{POS}$ & 92 & 3.73 & 0.927 & 0.018 & 0.134 & Not a Predictor \\
\hline Singapore & $\mathrm{H}_{2}$ & $\mathrm{SL}$ & 201 & 4.15 & 0.612 & 0.059 & $0.243^{*}$ & Predictor \\
& $\mathrm{H}_{3}$ & $\mathrm{POS}$ & 201 & 3.57 & 0.563 & 0.193 & $0.440^{*}$ & Predictor \\
\hline Malaysia & $\mathrm{H}_{2}$ & $\mathrm{SL}$ & 32 & 3.94 & 1.076 & 0.001 & 0.028 & Not a Predictor \\
& $\mathrm{H}_{3}$ & $\mathrm{POS}$ & 32 & 3.41 & 0.916 & 0.041 & 0.203 & Not a Predictor \\
\hline Thailand & $\mathrm{H}_{2}$ & $\mathrm{SL}$ & 54 & 4.13 & 0.802 & 0.195 & $0.442^{*}$ & Predictor \\
& $\mathrm{H}_{3}$ & $\mathrm{POS}$ & 54 & 3.67 & 0.869 & 0.115 & $0.339^{*}$ & Predictor \\
\hline Philippines & $\mathrm{H}_{2}$ & $\mathrm{SL}$ & 48 & 4.75 & 0.602 & 0.001 & 0.390 & Not a Predictor \\
& $\mathrm{H}_{3}$ & $\mathrm{POS}$ & 48 & 3.87 & 0.602 & 0.024 & 0.159 & Not a Predictor \\
\hline
\end{tabular}

Note: SL - Servant Leadership; POS- Perceived Organizational Support

${ }^{*}$ Regression is significant at the .05 level 
In addition, Table 3 unveils that teachers' affective commitment was influenced by work engagement behaviors in India ( $\left.\beta=.299, R_{2}=.089\right)$ and Singapore $(\beta=$ $\left..379, R_{2}=.144\right)$. Work engagement also had significant effect on normative commitment of teachers in Singapore $\left(\beta=.436, R_{2}=.192\right)$ and Thailand $(\beta=.415$, $\left.\mathrm{R}_{2}=.172\right)$.
Table 4 discloses that Organizational citizenship behavior directed to individuals (OCB-I) was significantly predicted by work engagement in Malaysia $\left(\beta=.537, R_{2}=.288\right)$ and Thailand $\left(\beta=.299, R_{2}=\right.$ .09) with somewhat strong and Moderate correlation respectively.

Table 3. Regression between Work Engagement and Organizational Commitment

\begin{tabular}{|c|c|c|c|c|c|c|c|}
\hline \multirow{3}{*}{ Hypotheses } & \multirow{3}{*}{ Country } & \multicolumn{6}{|c|}{ Organizational commitment } \\
\hline & & \multicolumn{2}{|c|}{ Affective } & \multirow{2}{*}{ Result } & \multicolumn{2}{|c|}{ Normative } & \multirow{2}{*}{ Result } \\
\hline & & $\mathbf{R}^{2}$ & B & & $\mathbf{R}^{2}$ & B & \\
\hline \multirow{5}{*}{$\mathrm{H}_{4}$} & India & .089 & $.299 *$ & Predictor & .005 & .068 & Not a Predictor \\
\hline & Singapore & .144 & $.379 *$ & Predictor & .192 & $.436^{*}$ & Predictor \\
\hline & Malaysia & .118 & .343 & Not a Predictor & .042 & .205 & Not a Predictor \\
\hline & Thailand & .111 & .333 & Not a Predictor & .172 & $.415^{*}$ & Predictor \\
\hline & Philippines & .013 & .116 & Not a Predictor & .018 & .134 & Not a Predictor \\
\hline
\end{tabular}

*Regressions is significant at the .05 level

Table 4. Regression between Work Engagement, Organizational Citizenship Behavior

\begin{tabular}{|c|c|c|c|c|c|c|c|}
\hline \multirow{3}{*}{ Hypotheses } & \multirow{3}{*}{ Country } & \multicolumn{6}{|c|}{ Organizational Citizenship Behavior } \\
\hline & & \multicolumn{2}{|c|}{ OCB- I } & \multirow{2}{*}{ Result } & \multicolumn{2}{|c|}{ OCB-O } & \multirow{2}{*}{ Result } \\
\hline & & $\mathbf{R}^{2}$ & B & & $\mathbf{R}^{2}$ & B & \\
\hline \multirow{5}{*}{$\mathrm{H}_{5}$} & India & .016 & .127 & Not a Predictor & .002 & .004 & Not a Predictor \\
\hline & Singapore & .013 & .114 & Not a Predictor & .034 & $.184^{*}$ & Predictor \\
\hline & Malaysia & .288 & $.537^{*}$ & Predictor & .22 & $.471^{*}$ & Predictor \\
\hline & Thailand & .090 & $.299 *$ & Predictor & .222 & $.469^{*}$ & Predictor \\
\hline & Philippines & .187 & .432 & Not a Predictor & .099 & $.315^{*}$ & Predictor \\
\hline
\end{tabular}

At the same time, work engagement accounts for little variance in Thailand (9\%) and moderate variance in Malaysia (28.8\%) on OCB-I. It was also noted that work engagement behaviors significantly organizational citizenship behaviors directed toward the organization (OCB-O) in Singapore, Malaysia, Thailand, and the Philippines. Work engagement behaviors had no effect on OCB-I and OCB-O among teachers in India 


\subsection{Discussion}

The findings of the current study support the motivational process of the Job Demand Resource model and the Organizational Support Theory among Montfortian teachers in Singapore and Thailand. The very high level of work engagement of teachers in the Philippines, India, and Thailand is supported by the latest news Ang (2018) in Singapore which noted the Aon's (2018) Trends in Global Employee Engagement Report. According to this global report, the employee engagement scores for the Philippines and India were $71 \%$, followed by Thailand (64\%), Malaysia (63\%), and Singapore (59\%). The results of Work Engagement among teachers in the Philippines are also consistent with another study in a private university in the Philippines also confirms that the work engagement level among the faculty was generally high (Bay, An, \& Laguador, 2014). The higher level of work engagement in the Philippines is also in line with the findings of Rayan et al (2015) among the government employees in Romblon, Philippines. The findings suggest that highly engaged teachers may enjoy wellbeing. They are great assets to their schools. They work with passion, take pride in their jobs and feel a profound connection to their schools. They drive innovation and move the organization forward. The lack of work engagement might suffer the quality of teaching and students' learning.

The difference in the level of work engagement behaviors among Montfortian teachers across Asian countries may be due to the fact that the work engagement behaviors of teachers are influenced by Work, Interpersonal relationships, organizational factors, and the National Culture of each country as suggested by Hofstede G., Hofstede, G.J, and Minkov (2011). There is limited evidence to support that National culture could account for the differences in the level of work engagement across countries in Asia. On the other hand, an interpersonal relationship such as co-worker support is significantly related to work engagement. The co-worker support is similar to Organizational citizenship behavior directed toward personnel in the organization. It has the motivational potential and enhances employees' feelings of absorption, dedication, and vigor. According to (Bakker \& Demerouti, 2007). The higher level of work engagement in the Philippines also is in line with a recent study by Rayan et al. (2018) that noted that the Montfortian teachers in the Philippines scored a high level of citizenship behavior directed toward co-workers. The differences in the level of work engagement may be explained by a Growth mindset, well-being, and perseverance of effort and other Organizational factors (Zeng, Chen, Cheung, \& Peng, 2019). It is important to note that the Montofortian Schools in the Philippines are supervised and administered by the Montfort Brothers from India. The Indian Brothers who administer the schools in the Philippines also could have influenced through their organizational culture to the Higher level of Work Engagement in the Philippines and India.

The influence of Job Resources such as Perceived organizational support and Supervisor support (Servant leadership) among Montfortian teachers in Thailand was supported by an empirical study that examined the antecedents and consequences of the work engagement model for Thai teachers. The findings confirm that job resources positively affected work engagement behaviors among Thai teachers (Choochom, 2016). The results in the context of Singapore and Thailand suggest that the school leadership is concerned 
about the growth of their teachers and the school administration recognizes the contribution of teachers and care for their well-being. In return, the teachers tend to work hard, involve, and feel happily engrossed. The findings also bring deeper meaning that the school heads are trusted by their teachers' as authentic and honest leaders who promote well-being and peace in the school community.

The effect of work engagement on organizational citizenship behaviors among teachers of Thailand was in line with the empirical study which confirmed that the Work engagement of Thai teachers had an impact on teachers' organizational citizenship behavior (Choochom, 2016). Work engagement behaviors had no effect on OCB-I and OCB-O among teachers in India. In another study by Rayan et al., (2018) noted that perceived organizational support had a weaker correlation with OCB- I among the Montfortian teachers in India.

The moderate and significant relationship between work engagement and OCB-O explains that the teachers in the Philippines value their organization as their family and are willing to work in a team. They may engage in extra vigor, dedication, and absorption in their work if they would work in a team. This is a sign of healthy organizations. Teachers who enjoy wellbeing can build healthy teams.

Montforitan school organizations must understand the importance of teachers' wellbeing through work engagement. The schools must promotethemotivational process of thejobdemand resource model through organizational resources. Engaged teachers are great assets to Montfortian schools. They contribute greatly through extrarole performance. Engagement of teachers will help their leaders to align teachers around school missions resulting in increased efficiency and productivity. The findings of the study might help the administration of Montfortian Schools to seek innovative and adaptable managerial interventions that are needed to improve the work engagement among teachers and to make stronger their organizational commitment and organizational citizenship behaviors. Thus, schools can promote the well-being of their teachers and healthy school organizations.

In managerial implication, this study has provided useful information to the Montfortian schools across countries in Asia. With this information, the school administration will be able understand that Work engagement is an important index for the quality of working life. It can be seen as a crucial factor in increasing the performance of the employee and, thereby, the organization's level of efficiency. To achieve this, urgent and concrete strategies must focus on the development of effective work engagement to enhance organizational commitment and citizenship behavior of teachers.

\subsection{Conclusion}

Based on the finding of the study, there are a few key points that can be used to conclude this research paper. The Montfortian teachers in India, Philippines, and Thailand always worked with more energy, enthusiasm and a higher level of concentration at work. They also might enjoy wellbeing through a higher level of work engagement. Work engagement behaviors of Montfortian teachers across the countries in Asia were practiced at different levels. Especially, teachers in the Philippines showed a higher level of energy, interest, and preoccupation at 
work compared to the teachers from Singapore, Malaysia, and Thailand. The School administrators' commitment to the growth and well-being of the teachers' influenced slightly the engagement of teachers' interest, energy, and concentration in their work in Singapore. It also had a considerable amount of effect on the teachers' work engagement in Thailand. Findings also suggest that the Montfortian teachers in Singapore and Thailand perceived that their organization recognized their contribution and cared for their well-being, the teachers were motivated to work with a higher level of work engagement. In India and Singapore, engaged teachers were influenced to be very happy and spend the rest of their career with their school. Engaged teachers in Thailand felt that their school deserves their loyalty and they have an obligation to stay with their current employer. In the context of Malaysia and Thailand, teachers' work engagement influenced them to become more helpful to their co-teachers in their work. Engaged Montfortian teachers in Singapore, Malaysia, Thailand, and the Philippines volunteered for extra work assignments, offered suggestions to improve the performance and said good things about their school organization to others. This study contributes significantly with key results to the human resources management of Montfortian schools in India, Singapore, Malaysia, Thailand, and the Philippines. Teachers' well-being has become critical to the well-being of the Montfortian schools. Therefore, it is paramount to promote teachers' wellbeing through work engagement and increase positive organizational outcomes.

This cross-sectional study is a single time snapshot of teachers' views. It also employed a self-reported survey. It is therefore suggested that a longitudinal study will be conducted using multiple sources of data. Further, a qualitative study should complement the quantitative study in order to understand the situation in a holistic manner. Geographical constraints and small sample sizes make the study less generalizable across samples. The study is an important contribution to the scarce research work that is done in the field of work engagement among Montfortian teachers across countries in Asia.

\section{References}

Agrawal, S. (2015). Predictors of employee engagement: A public sector unit experience. Strategic HR Review, 14(1/2), doi: 10.1108/SHR07-2014-0044

Akkoç, İ., Çalışkan, A. \&Turunç, Ö. (2012). Development culture in organizations and the effect of perceived work support on job satisfaction and work performance: the mediating role of trust. Journal of Management and Economics Celal Bayar University the Faculty of Economic and Administrative Sciences Journal, 19(1), 105-135.

Akhund A.\&Shamsul A. (2017). The effects of employee engagement on organizational commitment: A survey on junior executives working in the private sector of Bangladesh. Management Development. 31(1), 54-76.

Ang. J (2018, March 29). Singaporeans continue to be amongtheleastengagedinAsiaPacific. Retrieved from https://www.humanresourcesonline.net/ singaporeans-continue-to-be-among-theleast-engaged-in-asia-pacific/. 
Bakker, A. B., \&Demerouti, E. (2007). The job demands resources model: State of the art. Journal of Managerial Psychology, 22, 309-328.

Bakker, A. B., \& Leiter, M. P. (Eds.). (2010). Work engagement: A handbook of essential theory and research. Psychology Press.

Bakker, A. B., Schaufeli, W. B., Leiter, M. P., \&Taris, T. W. (2008). Work engagement: An emerging concept in occupational health psychology. Work and Stress, 22,187-200.

Bakker, A. B., Albrecht, S. L., \& Leiter, M. P. (2011). Work engagement: Further reflections on the state of play. European Journal of Work and Organizational Psychology, 20, 74-88. doi:10.1 080/1359432X.2010.546711

Bay,A.B.,An,I.L.,\&Laguador,J.M.(2014).Organizational satisfaction and work engagement of Filipino teachers in an Asian university. International Journal of Multidisciplinary Academic Research, 2(4), 32-41.

Chen, C.-Y., Chen, C.-H., \& Li, C.-I. (2013). The influence of leader's spiritual values of servant leadership on employee motivational autonomy and eudaemonic well-being. Journal of Religion and Health, 52(2), 418-438.

Choochom, O. (2016). A causal relationship model of teachers' work engagement. International Journal of Behavioral Science, 11, 143-152.

De Clercq D, Bouckenooghe D, Raja U, Matsyborska G. (2014). Servant leadership and work engagement: The contingency effect of leader-follower social capital. Human Resource Development Quarterly, 25:183-212.

Delaram Chehelmard (2013). Work engagement among secondary school teachers in Hyderabad, India. Business Sciences International Research Journal,1(2). Retrieved from http:// www.imrfournals.in/pdf/MATHS/BSIRJ-VOLUME1-ISSUE-2-2013/42.pdf on January 12, 2019.

Deligero, L. J, \&Laguador, J. M (2014).Work engagement among employees and its relationship with work units' performance of a higher education institution. International Journal of Management Sciences, 3(12), 909917.

Demerouti, E., Bakker, A. B., Nachreiner, F., \&Schaufeli, W. B. (2001). The job demands resources model of burnout. Journal of Applied Psychology, 86, 499 - 512.

Eisenberger, R., Huntington, R., Hutchison, S., \& Sowa, D. (1986). Perceived organizational support. Journal of Applied Psychology, 71, 500-507.

Fox, S., Spector, P. E., Goh, A., Bruursema, K. \& Kessler, S. R. (2012). The deviant citizen: Measuring potential positive relations between counterproductive work behaviour and organizational citizenship behaviour. Journal of Occupational and Organizational Psychology, 85, 199-220.

Greenleaf, R. K. (1977). Servant leadership: $A$ Journey into the nature of legitimate power and greatness. New York: Paulist Press. 
Høigaard, R., Giske, R, \&Sundsli, K. (2011). Newly qualified teachers' work engagement and teacher efficacy influences on job satisfaction, burnout, and the intention to quit. European Journal of Teacher Education. Retrieved from EURJTEACH EDUC. 35. 1-11. 10.1080/02619768.2011.633993.

Hofstede, G., Hofstede, G. J., \&Minkov, M. (2011). Kulturyiorganizacje: zaprogramowanieumysłu. Warszawa: PolskieWydawnictwoEkonomiczne.

Ilagan, J. L. T. \& Javier, F. V. (2014). Supervision and other determinants of employee morale: The case of Banco De Oro branches in Batangas City and Bauan, Philippines. Asia Pacific Journal of Multidisciplinary Research, 2(5), 138-149.

lyer, R. D. (2016). A study of work engagement among teachers in India. Global Business and Management Research, 8, 34-42.

Kataria, A., Garg, P., \&Rastogi, R. (2013). Psychological climate and organizational effectiveness: Role of work engagement. The IUP Journal of Organizational Behavior, 12 (3), 33-46.

Kim, W., Kim, J., Woo, H., Park, J., Jo, J., Park, S.-H., \& Lim, S. Y. (2017). The relationship between work engagement and organizational commitment: Proposing research agendas through a review of empirical literature. Human Resource Development Review, 16(4), 350-376. https:// doi.org/10.1177/1534484317725967

Klassen, R. M., Aldhafri, S., Mansfield, C. F., Purwanto, E., Siu, A. F. Y., Wong, M. W., \& Woods-McConney, A. (2012). Teachers' engagement at work: An international validation study. The Journal of Experimental Education, 80(4), 317-337. doi: 10.1080/00220973.2012.678409

Krishnan, J., \& Mary, V. S. (2012). Perceived organisational support-an overview on its antecedents and consequences. International Journal of Multidisciplinary Research, 2, 2-3.

Liden, R. C., Panaccio, A., Meuser, J. D., Hu, J., \& Wayne, S. J. 2014. Servant leadership: Antecedents, processes, and outcomes. In D. V. Day (Ed.) The Oxford handbook of leadership and organizations: 357- 379. Oxford, England: Oxford University Press.

Liden, R. C., Wayne, S. J., Zhao, H., \& Henderson, D. (2008). Servant leadership: Development of a multidimensional measure and multi-level assessment. The Leadership Quarterly, 19(2), 161-177.

Macey, W. H., \& Schneider, B. (2008). The meaning of employee engagement. Industrial and Organizational Psychology, 1, 3-30. Doi:17549426/08.

Meyer, J. P., Allen, N. J., \& Smith, C. A. (1993) Commitment to organizations and occupations: Extension and test of a three component model. Journal of Applied Psychology, 78, 538-551.

Montfortian Education Charter (2010). Montfortian education for the 21st century. Casa Generalisizia, Rome, Italy, 36-41.

Nurul, A.R., Jo, A.H. ,Siew, I.N., and Murali, S. (2015) Job demands \& job resources: 
Predicting burnout and work engagement among teachers. International Proceedings of Economics Development and Research (IPEDR), 84 .Retrieved from http://www.ipedr.com/ vol84/017-E00026.pdf on January 12, 2019.

Organ, D., Podsakoff, P., \& Mackenzie, S. (2006). Organizational citizenship behaviours: Its nature, antecedents, and consequences. Thousand Oaks: Sage publications.

Özdevecioğlu, M. (2003). A research on determining the relationship between perceived organizational support and organizational commitment. DokuzEylul University Faculty of Economics and Administrative Sciences Journal, 18 (2), 113-130.

Pakarinen, E., Kiuru, N., Lerkkanen, M., Poikkeus, A., Siekkien, M., \& Nurmi, J. (2010). Classroom organization and teacher stress predict learning motivation in kindergarten teacher well-being 20 children. European Journal of Psychology of Education, 25, 281-300. http:// dx.doi.org/10.1007/s10212-010-0025-6

Pasion-Caiani, T. S.(2015).Examination of employee alignment as a predictor of work engagement. Master's Theses. 4554. DOI: https://doi. org/10.31979/etd.ydep-ks65

Pati, S. P. (2012). Development of a measure of employee engagement. The Indian Journal of Industrial Relations, 48 (1), 94-104.

Pati, S. P., \& Kumar, P. (2010). Employee Engagement: Role of self efficacy: Organizational support and supervisor support. Indian Journal of
Industrial Relations, 46(1), 126-137.

Rayan, B. A. (2013). Montfortian technical vocational education and training schools in Asia: Charism and performance. European Social Sciences Research Journal, 1(4), 254-263.

Rayan, A. \& Dr, J. and Wong, J. (2018). Organizational citizenship behavior among Montfortian teachers: A cross national comparative study in Asia. Retrieved from https://www.researchgate.net/ publication/324965856_ORGANIZATIONAL_ CITIZENSHIP_BEHAVIOR_AMONG_ MONTFORTIAN_TEAHERS_A_CROSS NATIONAL_COMPARATIVE_STUDY_IN_ASIA/ Downloaded on November 24, 2019

Rayan, BA., Wong JP., Banas JL. P (2015, December) Influence of servant leadership among government employees in the province of Romblon, Philippines, International Journal of Humanities Social Sciences and Education (IJHSSE), 2(12),73-81.

Roozeboom, M.B. \&Schelvis, R. (2015). Work engagement: drivers and effects. Retrieved from http://oshwiki.eu/wiki/Work engagement:_drivers_and_effects

Ryan, R.M., \& Deci, E.L. (2011). A self-determination theory perspective on social, institutional, cultural, and economic supports for autonomy and their importance for well-being. In V.I. Chirkov (Ed.). Human autonomy in crosscultural context, 45-64. Netherlands: Springer. http://dx.doi.org/10.1007/978-90-481-96678_3 
Saks, A. M., \&Rotman, J. L. (2006). Antecedents and consequences of employee engagement. Journal of Managerial Psychology, 21(7), 600619.

Schaufeli, W. B. (2012). Work engagement what do we know and where do we go? Romanian Journal of Applied Psychology, 14 (1), 3-10.

Schaufeli, W., \& Bakker, A. B. (2004). Job demands, job resources, and their relationship with burnout andengagement. Journal of Organizational Behavior, 25, 293- 315.

Schaufeli, W. \& Bakker, A. (2004). Utrecht work engagement scale. Utrecht University: Occupational Health Psychology Unit.

Schaufeli, W. B., Salanova, M., Gonzalez-Roma, V., \& Bakker, A.B. (2002). The measurement of engagement and burnout and: A confirmative analytic approach. Journal of Happiness Studies, 3, 71-92.

Schaufeli, W.B. \& Salanova, M. (2007), "Work engagement: An emerging psychological concept and its implications for organizations", in Gilliland, S.W., Steiner, D.D. and Skarlicki, D.P. (Eds). Research in social issues in management, 135-177. Greenwich: Information Age Publishers.

Shimazu A., Schaufeli W. B., Kubota K.,\& Kawakami N. (2012). Do workaholism and work engagement predict employee well-being and performance in opposite directions? Ind. Health, 50, 316-321. 10.2486/indhealth. MS1355
Shuck, M. B., Rocco, T. S., \&Albornoz, C. A. (2011). Exploring employee engagement from the employee perspective: Implications for HRD. JournalofEuropeanIndustrialTraining, 35,300-325. https://doi.org/10.1108/03090591111128306

Steger, M. F., Littman-Ovadia, H., Miller, M., Menger, L.,\&Rothmann, S. (2013). Engaging in work even when it is meaningless: Positive affective disposition and meaningful work interact in relation to work engagement. Journal of Career Assessment, 21(2), 348-361.

Tepayakul, R. \& Rinthaisong, I. (2018). Job satisfaction and employee engagement among human resources staff of Thai private higher education institutions.The Journal of Behavioral Science, Vol. 13, Issue 2, 68-81.

Vorina, A., Simonič, M., \&Vlasova, M. (2017). An analysis of the relationship between job satisfaction and employee engagement. Economic Themes, 55(2), 243-262.

Winston, B. \& Fields, D., (2015). Seeking and measuring the essential behaviors of servant leadership. Leadership \& Organization Development Journal, 36(4), 413-434, https:// doi.org/10.1108/LODJ-10-2013-0135

Zeng, G., Chen, X., Cheung, H. Y., \& Peng, K. (2019). Teachers' growth mindset and work engagement in the Chinese educational context: Well-being and perseverance of effort as mediators. Frontiers in psychology, 10, 839. doi:10.3389/fpsyg.2019.00839 